\title{
CHALLENGES TO PEACEFUL PROTEST IN NIGERIA: THE USE OF FORCE
}

\author{
by Adebayo Okeowo*
}

\begin{abstract}
Everyone must be able to express their grievances or aspirations in a peaceful manner, including through public protests without fear of reprisals or of being intimidated, harassed, injured, sexually assaulted, beaten, arbitrarily arrested and detained, tortured, killed or subjected to enforced disappearance. ${ }^{1}$
\end{abstract}

\section{Introduction}

The freedom or the right to engage in peaceful protest is one that can be perceived to have been enshrined, and guaranteed, under the right to freedom of expression ${ }^{2}$ while also being closely linked to the right to freedom of association ${ }^{3}$ and freedom of speech. ${ }^{4}$ This right is a core feature and foundation of a democratic society as it ensures that the people's representatives can be interrogated in the people's court for any act not in conformity with the wishes of the people. ${ }^{5}$ Civil society groups are usually at the forefront of many protests - serving as the rallying point and the report by the Office of the High Commissioner for Human Rights (OHCHR) recently recognised this, stating that civil society plays a crucial role in the realisation of human rights on the ground. ${ }^{6}$

Unfortunately, most governments around the world feel threatened once faced with a group of people demanding accountability from government on specific issues. Their default response almost always is to shut down protests by resorting to the

* LLD candidate at the Centre for Human Rights, University of Pretoria.

Preamble, Human Rights Council Resolution 22/10 'The promotion and protection of human rights in the context of peaceful protests' March 2013.

Art 19(2) of the International Covenant on Civil and Political Rights (ICCPR).

3 Art 22 of the ICCPR.

4 Freedom of speech is not directly phrased as a right within international treaties but can, however, be delineated as a political right to hold and express one's opinions without interference and this is protected under art 19(1) of the ICCPR.

5 Wilton Park Conference Report 'Peaceful protest: a cornerstone of democracy How to address the challenges?' (26 - 28 January 2012) WP1154.

6 Report of the Office of the United Nations High Commissioner for Human Rights 'Summary of the Human Rights Council panel discussion on the importance of the promotion and protection of civil society space' (26 June 2014) A/HRC/27/33. 
use of force and other violent means. ${ }^{7}$ The civil society space is being eliminated by governments even as they continue to face threats, bans on peaceful demonstrations, confiscation of computers, imprisonments and even killings. ${ }^{8}$ This unfortunate reality was described by CIVICUS:

Democratic South Africa's National Assembly passed the so called "secrecy bill", which places hurdles against CSOs and journalists obtaining information to expose official wrongdoing, despite fierce civil society resistance.

Such laws are brought in and applied under a number of guises. Commonly, rhetoric around national security and controlling terrorist activities was used to justify new restrictions on fundamental freedoms in the years following the $9 / 11$ terrorist attacks in $2001 .^{9}$

Nigeria is not an exception to this unacceptable trend and this paper will look at how the use of force in Nigeria has become one of the biggest impediments to peaceful protests and has in some instances, resulted in fatalities.

\section{Use of force in Nigeria}

Security forces the world over are known to use excessive force in the execution of their duty as law enforcement officers. But it would seem that there is a particular notoriety that comes with the Nigerian Security Forces, especially the police. Aside from being perceived as the most corrupt institution in the country, ${ }^{10}$ the Nigerian police do not hesitate to use deadly force, and this comes as no surprise, because the Police Force Order 237 practically authorises a police officer to shoot on sight, irrespective of whether the target poses a threat or not. ${ }^{11}$ Several local and foreign organisations have called for the repeal of the Order as it directly contravenes the presumption of innocence and aids the violation of the right to life, which is fully

7 For instance, the government of Sudan deployed repressive tactics including excessive use of force involving live ammunition against protesters who held demonstrations between late September and early October 2013. See Amnesty International 'Sudan: Excessive and Deadly: The Use of Force, Arbitrary Detention and Torture Against Protesters in Sudan' http://www.amnesty.org/en/library/ asset/AFR54/020/2014/en/da16ca4b-6e61-4deb-9d0e-cbb3f85f6274/afr5402020 14en.html (accessed 29 September 2014).

8 UNHCHR (n 6 above) 4

9 CIVICUS State of civil society report 'A disenabling environment for civil society: push-back, persecution and protection strategies in 2011' (2011) 97.

10 O Chima 'Police, PHCN named as most corrupt institutions' 23 March 2011 http: // www.thisdaylive.com/articles/police-phcn-named-as-most-corrupt-institutions/ 88306/ (accessed 14 November 2015).

11 Amnesty International 'Nigeria: Loss of life, insecurity and impunity in the run-up to Nigeria's elections' (2011) Amnesty International Publications 8 
guaranteed under section 33 of the Constitution of Nigeria. ${ }^{12}$ However, to date, the Order is still in force.

'The Police is Your Friend' is a parlance within the Nigeria Police Force which citizens find to be inconsistent with reality. Several instances of police brutality, both within detention cells and in public spaces, have crushed any possible ardent relationship between Nigerians and those mandated to keep them safe.

Even though the Constitution guarantees the right to peaceful assembly and association, ${ }^{13}$ as well as the freedom of expression, ${ }^{14}$ holding a peaceful protest in Nigeria has increasingly become extremely difficult, if not impossible. The police force is always present to tear up peaceful rallies and protests using not just gas canisters but even guns. In January 2012, there was a coordinated civil disobedience to protest the removal of fuel subsidy by the Federal Government. During this period, economic activities ground to a halt and for about 7 days, Nigerians kept gathering peacefully at public spaces nationwide to protest the removal of the subsidy. However, before long, the streets became militarised, while in some states of the Federation, the police used lethal force on protesters that led to the death of at least 16 people. ${ }^{15}$

Further complicating the situation is the Public Order Act. ${ }^{16} \mathrm{~A}$ provision of the Act that states that a police license must be obtained prior to engaging in a peaceful protest, has been declared unconstitutional in the case of All Nigeria Peoples Party $v$ InspectorGeneral of Police. ${ }^{17}$ In this case, Justice Chinyere of the Abuja Federal High Court gave a historic verdict stating:

the requirement of police permit or other authority for the holding of rallies or processions in Nigeria is illegal and unconstitutional as it violates section 40 of the 1999 Constitution and Article 11 of the African Charter on Human and Peoples' Rights (Ratification and Enforcement) Act (Cap 10) Laws of the Federation of Nigeria, 1990. ${ }^{18}$

12 S33 of the Constitution of the Federal Republic of Nigeria 1999 (the Constitution) reads: 'Every person has a right to life, and no one shall be deprived intentionally of his life, save in execution of a criminal offence of which he has been found guilty in Nigeria.'

13 S40 states "Every person shall be entitled to assemble freely and associate with other persons or political party.'

14 S39 states 'Every person shall be entitled to freedom of expression, including freedom to hold opinions.'

15 Ladybrille '\#OccupyNigeria Video: CNN coverage - Nigeria rocked by second day of nationwide protests' 10 January $2012 \mathrm{http}$ ://ladybrillemag.com/occupynigeriavideo-cnn-coverage-nigeria-rocked-by-2nd-day-of-nationwide-protests/ (accessed 14 November 2015).

16 Laws of the Federation of Nigeria (1979) Chapter 382.

17 (2006) CHR 181.

18 F Falana 'Limits of police powers in Nigeria' 9 December 2013 http:// pmnewsnigeria.com/2013/12/09/limits-of-police-powers-in-nigeria/ (accessed 22 September 2014). 
In this case, the Judge issued an injunction restraining the Inspector General of Police and his agents 'from further preventing the Plaintiffs and other aggrieved citizens of Nigeria from organizing or convening peaceful assemblies, meetings and rallies ...' 19

The police appealed the judgment of the court. The Justices of the Court of Appeal however unanimously upheld the judgment of the Federal High Court.

This case lays a strong precedent but it has not been sufficient in curbing police excesses as it has suffered from lack of implementation. In November 2013, the police still reportedly fired gunshots and released teargas canisters in a bid to disperse a peaceful gathering of anti-corruption protesters. ${ }^{20}$ Also on the Police's fault sheet was an assault on Senator Magnus Abe, who was shot at with rubber bullets by the police during a rally in Port Harcourt. ${ }^{21}$

The Organisation for Security and Cooperation in Europe also support the position taken by Nigeria's Court of Appeal as it prescribes that spontaneous assemblies should be lawful and there should not be a requirement of prior permission but rather prior notice. 22

Nevertheless, the Nigerian police continue to suppress peaceful protests, a more recent instance being that targeted at the 'Bring Back Our Girls' movement. The protesters had to attempt to institute court proceedings to challenge the police ban placed on their right to peacefully protest the abduction of schoolgirls by the Boko Haram terrorist group. ${ }^{23}$

While it is understandable that in some instances force will have to be resorted to in maintaining law and order, such force need not be deadly, excessive or lethal. Unfortunately, these excesses have been the most difficult aspect to curb among Nigeria's security forces and with the backing of Order 237, the police are able to justify virtually every form of killing.

The use of lethal force should be seen as a last resort and the only condition under which it should be deployed is in the protection of life. In the event that lethal force is being resorted to, the principle

19 As above.

20 Premium Times 'Police disperse anti-corruption protesters in Abuja' 21 November 2013 http://premiumtimesng.com/news/150121-police-disperse-anti-corruptionprotesters-abuja.html (accessed 22 September 2014).

21 Sahara Reporters 'Police fire rubber bullets and teargas at Senator Magnus Abe in Port Harcourt' 12 January 2014 http://saharareporters.com/news-page/policefire-rubber-bullets-and-teargas-senator-magnus-abe-port-harcourt (accessed 12 January 2014).

22 OSCE Office for Democratic Institutions and Human Rights (ODIHR) Guidelines on freedom of peaceful assembly (2nd ed) (2010).

23 Agence France-Presse 'Bring back our girls campaign in court over Nigeria protest ban' 3 June 2014 http: / / www.telegraph.co.uk/news/worldnews/africaandindian ocean/nigeria/10872543/Bring-Back-Our-Girls-campaign-in-court-over-Nigeriaprotest-ban.html (accessed 14 November 2015). 
of proportionality should be adhered to. In other words, the extent of force used must not be disproportionate to the crime committed.

In Nigeria, the challenges experienced by civil society from engaging in peaceful protests do not entirely reflect the other diverse challenges faced by civil society groups. The recently passed anti-gay law by the Nigerian government, for example, restrains civil society groups from expressing opinions in defence of the rights of the LGBTI community. 24

\section{The responsibilities and limitations}

The right to protest, like many other rights, is not absolute. ${ }^{25}$ However, it needs to be established that the full enjoyment of this right should be the norm while any form of restriction should be the exception.

A peaceful protest requires no definition because it is easily recognisable - it is devoid of any form of violence. It must however be stated that the fact that it is a peaceful protest does not mean it will not have negative impacts on the state. For instance, a peaceful protest can lead to economic hardship especially if protesters are able to stage a successful boycott using trade union groups.

There are primarily two instances under which this right may be curtailed: to respect the rights of others, and for the protection of national security or public order. ${ }^{26} \mathrm{In}$ as much as states may limit this right under the foregoing circumstances, the Human Rights Committee has stressed that 'a law may not confer unfettered discretion for the restriction of freedom of expression on those charged with its execution. ${ }^{27}$ In other words, whatever limitations the state is imposing, such limitations must not impair the essence of this right.

Protesters have a duty to conduct themselves in an orderly and peaceful manner. But there an equal obligation on states to ensure that the rights of protesters are protected and the right to protest cannot be arbitrarily interfered with simply because the views and opinions being expressed do not conform with those held by the

24 S5(3) of the Same Sex Marriage (Prohibition) Act 2013 provides a sentence of ten years for anyone who advocates for gay rights.

25 Limitation clauses are introduced to ensure that certain rights are not absolute. The question however is usually not about whether certain rights can be limited but whether the extent of limitation is lawful within a democratic society. See Democracy Reporting International Briefing Paper 'Lawful restrictions on civil and political rights' (2012) 2.

26 Art 19(3) ICCPR.

27 Human Rights Committee General Comment 27, Freedom of Movement UN Doc CCPR/C/21/Rev.1/Add.9 para 13. 
government in power. ${ }^{28}$ The ability to welcome criticism should be one of the hallmarks of a democratic government.

\section{Significance of peaceful protest}

The aim of peaceful protests is to generate dialogue with the ultimate aim of having government abandon a previously held antipeople position or reverse an unpopular law. This has been seen to work in instances around the world where concessions are made. This was the case during the 'Occupy Nigeria' movement - a protest that started out demanding that the Nigerian government reverse the removal of fuel subsidies but eventually grew into national civil disobedience. ${ }^{29}$ Another relevant example is that of Yemen, which was ready to enter into discussions following the 2011 protests, demanding that the government respects freedom, equality and human dignity. ${ }^{30}$

There are several methods that civil society groups and the general public can resort to when carrying out peaceful protests and Sharp has curated 198 of such methods. ${ }^{33}$ Sharp in his list, classified these methods into three broad categories namely: non-violent protest and persuasion, non-cooperation, and non-violent intervention. ${ }^{32}$ The first category is one that is of particular concern to this paper - the non-violent protest and persuasion. It is worthy to note that this category itemises 54 methods, the practicality of which is hinged on the existence of a democratic system that recognises the freedoms articulated above (speech, assembly, expression, and association). No matter how peaceful or non-violent a protest is, if a society does not allow itself to be governed by democratic tenets, such peaceful protests will continue to be met with hostility from law enforcement agents.

28 Liberty 'Article 11 Right to protest and freedom of association' https://www. liberty-human-rights.org.uk/human-rights/what-are-human-rights/human-rightsact/article-11-right-protest-and-freedom-association (accessed 27 September 2014).

29 The resultant effect of the removal of the fuel subsidy was that fuel prices jumped from N65 per litre 'to N141 per litre. At the end of the protests however, the government took several steps back and fixed the fuel price at N97 per liter. It is believed that had the protests been sustained for longer than seven days, government would have entirely reverted back to the initial pump price of fuel. See O Emmanuel and B Ezeamalu '\#OccupyNigeria: One year later, the gains, the losses' 12 January 2013 https://www.premiumtimesng.com/news/114890-occupy nigeria-one-year-later-the-gains-the-losses.html (accessed 30 September 2014).

30 General Assembly HR/CT/741 March 2012.

31 G Sharp 'How nonviolent struggle works' (2013) The Albert Einstein Institution 21 - 46.

32 G Sharp The politics of non violent action, Part Two: The methods of non violent action (1973) 3. 
As has been seen in many instances, governments usually ignore peaceful protests, expecting that they will quickly dissipate. ${ }^{33}$ However, contrary to expectation, the strength of these protests grow, the demands ring louder and the numbers of protesters swell into thousands. Subsequently, government reacts, not by having a dialogue with the protesters, but by deploying its security agents to contain the protest and it is at this point that a disconnect occurs because the people are protesting not to have government unleash its police force on them but to have government listen to their grievances. Thus, what starts out as a peaceful protest degenerates into a clash between law enforcement agents and protesters.

\section{Provisions of international law}

International Law is saturated with provisions guaranteeing the right to protest. Beginning with Article 11 of the African Charter which provides that 'every individual shall have the right to freely assemble with others' to the International Covenant on Civil and Political Rights (ICCPR) which, under Article 19(2) guarantees as follows:

Everyone shall have the right to freedom of expression; this right shall include freedom to seek, receive and impart information and ideas of all kinds, regardless of frontiers, either orally, in writing or in print, in the form of art, or through any other media of his choice.

The Human Rights Council also provides for the rights of protesters. ${ }^{34}$ Through paragraphs 9 and 11, the resolution especially makes strong statements against the use of force:

9. Urges all States to avoid using force during peaceful protests, and to ensure that, where force is absolutely necessary, no one is subject to excessive or indiscriminate use of force.

11. Affirms that nothing can ever justify "shoot to kill" practices as well as indiscriminate use of lethal force against a crowd, acts which are unlawful under international human rights law.

The resolution goes further under paragraph 10 to call on states to ensure that their domestic laws are in tandem with international standards. It also urges states to abide by the applicable principles of law enforcement in relation to proportionality in order to ensure that lethal force is only deployed in the face of an imminent threat to life.

33 A very recent example is the youth led pro-democracy protest in Hong Kong which initially started out as sit ins but eventually had the police using force to disperse the crowd, see J Pomfret \& $Y$ Lee 'Democracy protests in Hong Kong turn violent' 27 September $2014 \mathrm{http}$ ://www.huffingtonpost.com/2014/09/27/hong-kongdemocracy-protest_n_5892862.html (accessed 30 September 2014).

34 UN doc A/HRC/25/L.20 'The promotion and protection of human rights in the context of peaceful protests'. 
In General Comment No 34, the Human Rights Committee affirmed that the freedom of expression is a key component of the enjoyment of the rights to freedom of assembly and association. ${ }^{35}$ Also underscoring the global concern for the use of force during peaceful protests, the United Nations Human Rights Council in 2010 appointed a Special Rapporteur on the Rights to Freedom of Peaceful Assembly and of Association. ${ }^{36}$

\section{Conclusion}

In the case of Nigeria, it is necessary that international human rights standards are adhered to. This will include abolishing laws such as the Public Order Act and the Police Force Order, while enacting domestic legislations that tackle management of peaceful assemblies in conformity with what is expected under a democratic society. Protecting protesters still falls within the ambit of state obligation to protect its citizens from human rights violations including those by state agents and other third parties.

Nigeria must recognise that the vibrancy of democracy is partly premised on the ability of the citizenry to disagree with government policy and, through peaceful protests, bring the same to the attention of the state. Peaceful protests must therefore not be instinctively seen as a threat to public order but as a process necessary for the strengthening of democracy.

35 Human Rights Committee General Comment No 34 CCPR/C/GC/34 para 4

36 Resolution adopted by the Human Rights Council A/HRC/RES/15/21 The rights to freedom of peaceful assembly and association (6 October 2010) para 5. 